UNRAM Law Review is licensed under a Creative Commons Attribution 4.0 International License, which permits unrestricted use, distribution, and reproduction in any medium, provided the original work is properly cited. p-ISSN: 2548-9267 | e-ISSN : 2549-2365, Open Access at : http://unramlawreview.unram.ac.id/index.php/ulr

\begin{tabular}{c|c|c|c|c|}
\hline Volume & Issue & Page & October & p-ISSN: 2548-9267 \\
\hline 4 & 2 & $184-192$ & 2020 & e-ISSN : 2549-2365
\end{tabular}

\title{
Problematics of the Village Government Authority
}

\author{
Ahmad Yamin \\ Institut Ilmu Sosial dan Ilmu Budaya Samawa Rea Sumbawa Besar Nusa Tenggara Barat \\ Jl. Olat Maras, Desa Pernek Kecamatan Moyo Hulu Kab. Sumbawa \\ Email: ahmadyamin@gmail.com
}

\section{Supriyadi}

Institut Ilmu Sosial dan Ilmu Budaya Samawa Rea Sumbawa Besar Nusa Tenggara Barat

Jl. Olat Maras, Desa Pernek Kecamatan Moyo Hulu Kab. Sumbawa

Email: supriyadishi@yahoo.co.id

\begin{abstract}
The purpose of this research is to analyze the authority problems of the village government. This is a doctrinal legal research by examining legal materials from libraries or research libraries to obtain secondary legal material from books, articles, research results, and regulations, as well as experts relating to the exercise of villages authority. The solution offered is that the authority of the village government will run well when it is support by the authority of recognition and subsidiarity and the availability of human resources who have expertise and skills and apply good governance to create a village social welfare.
\end{abstract}

Keywords: Village authority; village government; recognition.

\section{INTRODUCTION}

Article 18B paragraph (2) of the 1945 Constitution of the Republic of Indonesia (hereinafter referred to as the constitution) states that "The State recognizes and respects indigenous peoples and their traditional rights as long as they are still alive and in accordance with the development of society and the principles of the Unitary State of the Republic of Indonesia which are regulated in regulation". Furthermore, in considering point $b$ of the Act Number 6 Years 2014 on Villages (hereinafter referred to as the village law), it is stated that in the villages have developed in various forms so they need to be protected and empowered to become strong, advanced, independent, and democratic that they can create a strong foundation. in carrying out government and development towards justice, prosperous and welfare. To be able to carry out a strong, advanced, independent, and democratic government and village development, the authority given by attribution by-laws to the village become the basis for formulating policies at the village level.

Article 18 of the village law, Village authority in general, includes authority in the field of Village Administration, Village Development Implementation, Village Community Development, and Village Community Empowerment based on community initiatives, 
rights of origin, and customs ${ }^{1}$. the authority is the embodiment of the political decentralization scheme and government administration. To build village autonomy, government autonomy must also be followed so that the distribution of authority does not stop at the Regency/City level, but also at the Village level ${ }^{2}$. This is understandable considering the position of the village in the Regency/City area, as stated in Article 5 of the village law that: "The village is located in the Regency/City area." As evidence that villages are inseparable from city districts as stipulated in Article 371 paragraph (1) of The Act Number 23 Years 2014 on Local Government, which states: "In Regency/ city Local government a Village government is formed consisting of the Village government and Village consultative bodies."

Geographically, village and regency/city authority are regulated in 2 (two) the Act regarding decentralization, The Act Number 6 Years 2014 concerning and The Act Number 23 Years 2014.This is proving that villages are a sub-systemor part of the regency/city government, on administratively, the village exercises position of the authority of the regency/city government. As an administrative consequence in exercising part of the authority from above, villages will receive a budget transfer in the form of Village Fund Allocation from the regency/city. Besides, villages receive budget transfers from the Central Government in the form of Village Funds, which are transferred through the regency/city. Such regulatory conditions will create conflicts of authority in budget management between districts/city and villages. Such conditions will affect the village's independence in carrying out its public service functions as mandated in the village law. ${ }^{3}$

In implementing the budgetary authority for development as stated in Article 74 paragraph (1) of the villagelaw that village expenditure is prioritized to get development needs agreed upon in village deliberations and following the priorities of the Regency/City Government, Provincial Government, and Government. In terms of Village revenue originating from the State Revenue and Expenditure Budget, the Provincial Revenue and Expenditure Budget, and the Regency/City Regional Revenue and Expenditure Budget are through the Regency/ City Regional Revenue and Expenditure Budget. So that the Regency/city Government has strategic authority in the Village financial management because it is a government unit directly above the Village.

Regulations regarding development planning at the village level are also regulated in Article 6 paragraph (1) Ministerial Regulation for Disadvantaged Regions and Transmigration Number 17 Years 2019 on General Guidelines for development and empowerment of village communities states that "Village Development Planning as referred to in Article 5 paragraph (1) letter a, arranged by the Village Government under the village authority based on the rights of origin and the village-scale local scale authority regarding regency/city development planning". ${ }^{4}$ The provisions of the above prove that the village authority's implementationof either authority origins and local authorities still refer to the village scale development planning Regency/City.

\footnotetext{
${ }^{1}$ Jimly Asshiddiqie. (2015). Gagasan Konstitusi Sosial: Institusionalisasi dan Konstitusionalisasi Kehidupan Sosial Mas yarakat Madani. Jakarta : Pustaka LP3ES.

2 Didik Sukriono. (2013). Hukum, Konstitusi dan Konsep Otonomi: Kajian Politik Hukum tentang Konstitusi, Otonomi Daerah dan Desa Pasca Perubahan Konstitusi. Malang: Setara Press, p. 195.

${ }^{3}$ Ahmad Yamin. (2020). Otonomi penyelenggaraan Pemerintahan Desa, Disertasi Program Doktor Ilmu Hukum Univer sitas Mataram. Mataram: Universitas Mataram, p.15.

${ }^{4}$ Permen PDTT Nomor 17 Tahun 2019 tentang Pedoman Pembangunan dan Pemberdayaan Masyarakat Desa.
} 
Normatively, the authority to run the government, development, and empowerment adjusted to the district/city's development policies. The implementation of this has not been optimal because it is not followed by competent human resources considering village government administrators' average education level starting from the village head. Village secretaries, heads of affairs, section heads in the village still have high school education or the equivalent. Only a small number of village government administrators have graduated from the university.

Theadministrators' government condition with secondary education competence is an obstacle to planning at the village level and managing village funds from government above both in Village Funds and Village Fund Allocation. The hope of implementing Good Governance management becomes hard to implement.

\section{METHOD}

The research is doctrinal legal research by examining materials derived from libraries or library research conducted to obtain secondary data from materials in the form of books, articles, research results, and regulations and implementing regulations. Others are related to village authority as well as expert opinions relating to the implementation of village authority. Legal materials related to this legal research are analyzed prescriptively by conducting analysis that returns to three aspects, classifying, comparing, and linking. In other words, the researcher does not merely purpose to reveal the truth, but also understand the truth. Legal materials that have been collected from library research will be analyzed prescriptively to answer the proposed research problems.

\section{ANALYSIS AND DISCUSSION}

\section{Implementation of the authority of the Recognition and Subsidiarity in the Village}

In-state administrative law, the legality principle has the meaning of dat het bestuur aan wet is onderworpnen; that the government is obeying to the law. This principle is the implementation of the legality principle in the context of state administrative law. To implemented the authority of the village government, it can be seen in Article 18 and Article 19 of the village law. Article 18 states, "Village authority includes authority in the field of village administration, village development, village community development, and village community empowerment based on community initiatives, rights of origin, and village customs."Thus, Article 19 states: Village authority includes: a. authority based on rights of origin; b. village scale local authority; c. authorities assigned by the government, provincial government, or regency/city government; and D. other authorities assigned by the government, provincial government, or regency/ city government following the provisions of regulations. In the context of implementing the authority granted by the Village Law accumulated in 2 (two) leadingauthorities:

Authority of Recognition.

According to Article 39 paragraph (1) Government Regulation Number 47 Years, 2015 on amendments to government regulation number 43 Years 2014 on implementation regulations of The Act number 6 Years 2014 onVillages states that "Further provisions regarding the 
determination of Village authority regulated by a ministerial regulation that organizes government affairs in the field of domestic government." Based on these provisions in 2016, the Minister of Home Affairs Regulation Number 44 Years 2016 on Village Authority was issued. According to the Minister Home Affairs, details of village authority according to origin include the customary community organization system; customary community institutional development, customary law, and institution development; Village treasury land management. Furthermore, according to Permendes Number 1 years 2015, the state recognizes the existence of village authority. It is explicitly explained that the scope of authority based on the rights of origin of the Village includes: a. Village apparatus organizational system; b. indigenous peoples' organizational system; c. community institutional development; d. development of customary law and institutions; e. Village treasury land management; f. management of Village land or Village-owned land using the local designation; g. crooked soil management; $h$. pecatu land management; i. titisara land management; and J. development of the role of the Village community. The authority of recognition, in this case, relates to the institutionalization and local rights of indigenous peoples.

Recognition authority is constitutionally stated in article 18 paragraph (2) as the basis of the Villages law, states: The state recognizes and respects customary law and their traditional rights as long as they are still alive and under the development of society and the principles of the Unitary State of the Republic of Indonesia as regulated in the Act. In this article, there is no mention of the village, only the customary law community unit and traditional rights. However, according to Article 1 number (1) of the Village Law: "customary villages and villages or what is called by other names, starting now referred to as villages are legal community units that have territorial boundaries that are authorized to regulate and administer government affairs, the interests of local communities based on community initiative, rights of origin, and/or traditional rights that are recognized and respected in the government system of the Unitary State of the Republic of Indonesia." From that statement can be explained that the Village Law states that a village is a village and customary village or what is called by other names. Villages and Traditional Villages or what are referred to other terms are legal community units. Concerning Article $18 \mathrm{~B}$ paragraph (2), there is a customary law community unit still has traditional rights that are still alive and developing by community development and the principles of the Republic of Indonesia that are recognized and respected.

Thus, in the General Explanation of the Village Law also stated that the construction of combining self-growing communities with local self-government. It is hoped that the customary law community units have been part of the Village area and organized,so Villages and Traditional Villagesperform almost the same task. In comparison, the only difference is in the implementation of the rights of origin, especially regarding the social preservation of the Traditional Village, the regulation and management of customary territories, the customary peace session, the maintenance and order for the customary law community, and the regulation of the implementation of government based on the original structure.

In principle, the Traditional Village is an incision of local community government organizations that are maintained from generation and are still recognized and fought for by their leaders and the Traditional Village people. Hence, they function to develop welfare and local socio-cultural identity. The Traditional Village has the origin right, which is dominant 
than the village's right of origin since the Traditional Village was born as an indigenous community that exists in the community. Traditional Village is a customary law community unit with historically had territorial boundaries and cultural identity formed on a territorial basis. There has the authority to regulate and manage the interests of the Village community's right of the origin. Customary law community units are formed based on three basic principles, genealogical, territorial, and/or genealogical combination with territorial, which is meant in the Village Law is a customary law community unit which is a combination of genealogical and territorial. In this connection, the state recognizes and respects the unity of indigenous peoples and their traditional rights as long as they are still and following society's development and the principles of the Unitary State of the Republic of Indonesia. The implementation of the customary law community unit already exists and lives in the territory of the Unitary State of the Republic of Indonesia, such as huta/nagori in North Sumatra, gampong in Aceh, nagari in Minangkabau, marga in southern Sumatra, tiuh or pekon in Lampung, pakraman village/village adat in Bali, lembang in Toraja, banua, and wanua in Kalimantan, and lands in Maluku. ${ }^{5}$ As mentioned above, the customary law community unit is an implementation of the authority of the origin (recognition) of the village.

In line with the above, SutoroEko ${ }^{6}$ determines the concept of recognition as the first principle for the village's position in the Village Law is based on several reasons. First, the village or what is called by another name, as a customary law community unit, is a different entity from the legal community unit known as a region. Second, a village or what is referred to another termthat existed before the Republic of Indonesia was born in 1945. It already has an original structure and carries the right of the origin. Third, the village is part of Indonesia's diversity or multiculturalism, which cannot be uniformed automatically. Fourth, in a long historical trajectory, the village has structurally been an arena for exploiting land and people while being mistreated, starting from the kingdom era, colonial rule, to the Indonesian government. Fifth, the constitution has given a mandate to the state to recognize and respect villages or what is referred to by other names as a customary law community unit and its traditional rights.

\section{Subsidiarity Authority}

Subsidiarity authority by the village government is inseparable from the principle of decentralization. The essence of the two principles is the distribution of power. The principle of decentralization in the context of the Unitary State of Romli in Didik G Suharto ${ }^{7}$ differsbetween an administrative perspective and a political perspective. Meanwhile, political decentralization is based on or oriented towards the main objective of decentralization, to create democracy at the local level and improve people's welfare. The administrative decentralization perspective is oriented towards the efficiency of regional government administration and regional scale development management. Departing from the definition, two goals/views of decentralization

\footnotetext{
${ }^{5}$ Lastuti Abubakar. (2013). "Revitalisasi Hukum Adat Sebagai Sumber Hukum Dalam Membangun Sistem Hukum Indo nesia”. Jurnal Dinamika Hukum, 11(2): 319-331.

${ }^{6}$ Sutoro Eko, dkk. (2014). Desa Membangun Indonesia, Cetakan Pertama, Yogyakarta: Forum Pengembangan Pembaha ruan Desa (FPPD), p. 2.

${ }^{7}$ Didik Gunawan Suharto, Dampak Perubahan Struktur dan fungsi Kelembagaan Pemerintahan Desa terhadap Ke mandirian Desa, Disertasi, Program Studi Doktor Ilmu Adaministrasi Negara Universitas Brawijaya. Malang : Univer sitas Brawijaya, p. 38
} 
must go together, lest there be disparities. When the government only prioritizes democratic values, it is alleged that it will ignore effectiveness and efficiency, and vice versa.

It becomes interesting when linked between the subsidiarity principle of decentralization, the villagelaw's authority, whether the village authority is one form of decentralization that will be followed by the autonomous authority. It can be seen from the law on the formation of the village. The purpose of the establishment of the village law on this village as written in the preamble :

1) The village has theorigin right and traditional right to regulate and manage the interests of the local community and contribute to realizing the ideals of independence by the Constitution of the Republic of Indonesia Year 1945;

2) In the course of the Republic of Indonesia's state administration, the Village has developed in various forms. They need to be protected and empowered to become strong, advanced, independent, and democratic, create a strong foundation in implementing governance and development towards a just, prosperous and welfare, and that the village in the composition and procedures of governance and development need to be governed by the laws.

Regarding of the subsidiarity authority, there are contra norms with several articles in Government Regulation Number 60 Years 2014 On Village Funds ${ }^{8}$ Sourced from the State Revenue and Expenditure Budget, Article 7 paragraph (1) states that: Management of village funds in the district/city APBD is implemented according to the provisions of laws and regulations in the field of regional financial management. Besides, Article 22, Paragraph 3 states that the regent/mayor can make technical guidelines for activities funded from village funds following the general guidelines for activities as stipulated in the Village Law's implementing regulations.It will injure thesubsidiarity authority due to intervention and domination of the supra-village government (local government) is very dominant.So the village will become dependent on the supra-village government, and the principle of subsidiarity is no longer implemented. In the end, the ideals of realizing an independent village and village level democracy will encounter difficulties.

\section{Human Resource Problems}

Human resources are the main factor for the sustainability of an organization anddetermining factors for measuring success and achieving organizational goals. Human resources in question are ready to use and have the ability to achieve organizational goals.Forit within the organization, increased needed empowerment. Empowerment is an attempt to make human resources more responsible for their work, which can improve their performance.

They empower people by moving them from a position where they are doing what they are told to do into a position that allows them to be more responsible ${ }^{9}$. Empowerment is the giving responsibility and authority from the leadership to employees, which involves sharing information and knowledge to guide employees in acting in accordance with organizational goals $^{10}$.

\footnotetext{
${ }^{8}$ Seek Peraturan Pemerintah Nomor 50 Tahun 2014 Tentang Dana Desa.

${ }^{9}$ Wibowo. (2011). Budaya Organisasi: Sebuah Kebutuhan Untuk Meningkatkan Kinerja Jangka panjang. Jakarta: Ra jawali Pers.

${ }^{10}$ Baron, L.L., \& Rue, L.W. 1997. Human Resource Management: Global Strategies for Managing A Diverse Workforce. New Jesey: Prentice Hall Inc
} 
According to Khan ${ }^{11}$, Empowerment is a continuous relationship between personal to build trust between employees and leaders. While Mulyadi and Setyawan argue that Empowerment is the granting of authority to employees to plan, control, and make decisions on the work for they are responsible for without having to get explicit authorization from managers at upon them. Also, empowerment is an effort that can significantly strengthen confidence in the authority to make decisions in areas of operational activities without having to obtain approval from others ${ }^{12}$.

Human resources administering the village government, often referred to as village government officials are empowered to provide public services at the village level. Apparatus comes from the word "apparatus," which means tool, while the word apparatus implies the same meaning as state apparatus as employees. So the apparatusis instruments that carry out the state's duties, which are appointed by the village head as public officials to provide public services at the village level. According to Soewarno Handayaningrat ${ }^{13}$, the apparatus is the administrative aspects needed to administer the government/state to achieve national goals. General village government officials are required to have knowledge and skills in running village governance. Inline, Miftha Thoha argues that "Ability is one of the elements related to knowledge or skills that employees acquire through education and training or work experience". In this case, the ability of the apparatus depends on the knowledge, skills, or abilities. The level of knowledge is seen through the formal education level, non-formal education such as training and upgrading courses, work experience. Thus, at the skill or proficiency level, it is seen through the way the work is carried out, the timing of the work, and the results achieved ${ }^{14}$. This leads to a conception that their ability shows the abilities possessed by an apparatus according to the level of knowledge and skills acquired through education and experience.

However, the fact is contrary in the field that village government officials' capacity, in general, in West Nusa Tenggara Province, especially in Sumbawa Regency, village officials are required to have a minimum high school education/equivalent. In contrast, the workload given to village government officials is at least with bachelor qualifications. This is one thing as a benchmark for measuring the capacity of village officials. Lower capacity and education qualification village officials make it difficult to make the village into development planning at the village level. There are many cases of misuse of budget funds and the Rural Village Allocation Fund involving village officials.

One of the smallest obstacles faced by village officials inoperating computers is running thevillage's administrative activities. Although this is small, this is very important because village officials' skills in operating computers are needed in the digitalization era. The digital age demands that village officials provide public services required to use information technology applications with internet networks to offer maximum public services based on good governance principles. The apparatus's inadequate competence will impact the village administration and public services less than optimal so that the provision of quality resources and technical skills is needed to realize good governance to create a social welfare village.

\footnotetext{
${ }^{11}$ Khan, S. (2007). The Key Being a Leader Company Empowerment. Journal for. Quality and Participation. New Jersey

${ }^{12}$ Luthans, F . (1995). Organizational Behavior. Tokyo: Mc Graw-hill Kogakhusa. Ltd.

${ }^{13}$ Handayaningrat, Soewarno. (1995). Pengantar Studi Ilmu Administrasi dan Manajemen. Jakarta: PT. Toko Gunung Agung.

${ }^{14}$ Miftah, Thoha. (2007). Kepemimpinan Dalam Manajemen. Jakarta: PT. RajaGrafindo
} 


\section{Alternative Solutions}

The solutions are offered to the village official need technical guidance and assistance in village development planning and provide a comprehensive understanding of the authority possessed by the village both recognition authority and subsidiarity authority by applying the principles of good governance with synergy approach between the Village government, the community and the private sector to carry out village development to realize social welfare villages. Then, the concept of an embodiment of good governance at the village level with the offer of a Social welfare Village model is an option to lead to village independence.

Social Welfare Village is a village where the community has high self-reliance, participation, and kinship, which is call (Swapake) to get basic needs and develop sustainable livelihoods and create added value for the village productivity, significantly to increase village original income.

Social welfare Village proves an insight or perspective about the village. The village is seen as a collective social entity with distinctive (specific) sociological, economic, cultural, and ecological characters compared to cities. The perspective views a village as a place where it comfort, harmony, peace, and tranquility are maintained not only wishful but also to be realized in reality by combining the authority of recognized authority and subsidiarity at the village level.

Social Welfare Village Characteristics and Targets

In general, the Social Welfare Village has the following characteristics:

1) The village ability to take care of itself with the strength it has;

2) The village government has the authority that is supported by independence in planning budgeting, implementation of development, and supervision of development oriented towards the welfare of the people.

3) The village government system upholds village people's aspirations and participation, including the poor, women, young people, disabilities, people with social problems, and other marginalized.

4) Development resources are managed in an optimal, transparent, accountable, participative manner to be used as well as possible for social welfare.

\section{CONCLUSION}

From the above discussion, it can be concluded that:

1. Recognition Authority is the implementation of Article 18B paragraph (2) of the 1945 Constitution of the Republic of Indonesia, which is implemented by the village law with an emphasis on social preservation of Traditional Villages, regulating and managing customary territories, peace sessions custom, maintenance and order for the customary law community, as well as the implementation of governance based on the original composition.

2. Subsidiarity authority is an implementation of the decentralized authority of the superior village government given to the village in the form of government administration, development, guidance, and empowerment to the community, as well as the assignment authority of the superior village government. 
3. The human resource problem is that villages have to prepare human resources for a government official who has the expertise and skills to provide optimal public services following the principles of good government governance at the village level so that they can create social welfare villages.

\section{Bibliography}

Books:

Baron, L.L., \& Rue, L.W. (1997). Human Resource Management: Global Strategies for Managing A Diverse Workforce. New Jesey: Prentice Hall Inc.

Didik Sukriono. (2013). Hukum, Konstitusi dan Konsep Otonomi: Kajian Politik Hukum tentang Konstitusi, Otonomi Daerah dan Desa Pasca Perubahan Konstitusi. Malang: Setara Press.

Handayaningrat, Soewarno. (1995). Pengantar Studi Ilmu Administrasi dan Manajemen. Jakarta: PT. Toko Gunung Agung.

Jimly Asshiddiqie.(2015). Gagasan Konstitusi Sosial: Institusionalisasi dan Konstitusionalisasi Kehidupan Sosial Masyarakat Madani. Jakarta: Pustaka LP3ES.

Luthans, F. (1995). Organizational Behavior. Tokyo: Mc Graw-hill Kogakhusa. Ltd.

Miftah, Thoha. (2007). Kepemimpinan Dalam Manajemen. Jakarta: PT. Raja Grafindo.

Sutoro Eko, dkk. (2014). Desa Membangun Indonesia, Cetakan Pertama. Yogyakarta: Forum Pengembangan Pembaharuan Desa (FPPD.

Wibowo. (2011). Budaya Organisasi: Sebuah Kebutuhan Untuk Meningkatkan Kinerja Jangka Panjang. Jakarta: Rajawali Pers.

Paper and Journal:

Ahmad Yamin. (2020). Otonomi penyelenggara Pemerintahan Desa. Disertasi Program Doktor Ilmu Hukum Universitas Mataram. Mataram: Fakultas Hukum Universitas Mataram.

Didik Gunawan Suharto. (2012). Dampak Perubahan Struktur dan fungsi Kelembagaan Pemerintahan Desa terhadap Kemandirian Desa, Disertasi, Program Studi Doktor Ilmu Adaministrasi Negara Universitas Brawijaya. Malang: Universitas Brawijaya.

Khan, S. (2007). The Key Being a Leader Company Empowerment. Journal for Quality and Participation: New Jersey.

Lastuti Abubakar. (2013). "Revitalisasi Hukum Adat Sebagai Sumber Hukum Dalam Membangun Sistem Hukum Indonesia”. Jurnal Dinamika Hukum 11 (2): 319-331.

Regulation:

Undang-undang Nomor 6 Tahun 2014 Tentang Desa.

Peraturan Pemerontah Nomor 47 Tahun 2015 Tentang Peraturan Pelaksanaan Undang-undang Nomor 6 Tahun 2014 Tentang Desa.

Peraturan Pemerintah 60 Tahun 2014 Tentang Dana Desa.

Peraturan Menteri Desa (PDTT) Nomor 1 Tahun 2015 tentang Kewenangan Desa.

Peraturan Menteri Dalam Negeri No. 44 Tahun 2016 Tentang Kewenangan Desa. 